Jurnal Psikologi

Volume 43, Nomor 2, 2016: 85 - 106

\title{
Peranan Kepuasan Kebutuhan Dasar Psikologis dan Orientasi Tujuan Mastery Approach terhadap Belajar Berdasar Regulasi Diri
}

\author{
St. Nurjannah Yunus Tekeng', Asmadi Alsa \\ Fakultas Psikologi Universitas Gadjah Mada
}

\begin{abstract}
This research aims at empirically examining the role of basic psychological need satisfaction and mastery approach goal orientation toward the self-regulated learning of the university students. The subject of this research consisted of 240 students the third, the fifth, and the seventh semester students of the faculty of education and teaching at the State Islamic University Makassar derived from eight departments. The sample taken by using multi stage cluster random sampling tecnique. The research instruments used were the self-regulated learning scale, the psychological basic need scale, and the mastery approach goal orientation scale. The data analyzed by using multiple regression analysis. The result shows that the value of Fregression $=115.303$, and the value of $p<0.001$. This means that the hypothesis of this research is accepted or the basic psychological need together with the mastery approach goal orientation can significantly predict the selfregulated learning of the university students with effective contribution $R^{2}=0.493$ or $49.3 \%$. Partially, the two predictors showed a different contribution where the basic psychological need satisfaction contributed $4.9 \%$ and the mastery approach goal orientation contributed $44.4 \%$ to the self-regulated learning of the university students.
\end{abstract}

Keywords: basic psychological need satisfaction, goal orientation, mastery approach, selfregulated learning

Abstrak. Penelitian ini bertujuan untuk menguji secara empiris peranan kepuasan kebutuhan dasar psikologis dan orientasi tujuan mastery approach sebagai prediktor belajar berdasar regulasi diri mahasiswa. Subjek penelitian berjumlah 240 mahasiswa semester III, V, dan VII Fakultas Tarbiyah dan Keguruan di Universitas Islam Negeri Makassar yang berasal dari delapan prodi. Teknik pengambilan sampel menggunakan multi stage cluster random sampling. Instrumen penelitian yang digunakan adalah skala belajar berdasar regulasi diri, skala kepuasan kebutuhan dasar psikologis, dan skala orientasi tujuan mastery approach. Data dianalisis dengan menggunakan uji regresi berganda. Hasilnya menunjukkan nilai $F_{\text {regresi }}=115,303$ dan nilai $p<0,001$. Ini berarti bahwa hipotesis penelitian ini dapat diterima atau dengan kata lain kepuasan kebutuhan dasar psikologis dan orientasi tujuan mastery approach secara bersama dapat secara signifikan memprediksi belajar berdasar regulasi diri mahasiswa dengan sumbangan efektif sebesar $R^{2}=0,493$ atau $49,3 \%$. Secara parsial, kedua variabel memberikan nilai kontribusi yang berbeda, dimana kepuasan kebutuhan dasar psikologis memberikan sumbangan efektif sebesar $4,9 \%$ dan orientasi tujuan mastery approach memberikan sumbangan efektif sebesar $44,4 \%$ terhadap belajar berdasar regulasi diri mahasiswa.

Kata kunci: belajar berdasar regulasi diri, kepuasan kebutuhan dasar psikologis, orientasi tujuan mastery approach

\footnotetext{
1 Korespondensi mengenai isi artikel ini dapat dilakukan melalui: st.nurjannah@uin-alauddin.ac.id, asmalsa@ugm.ac.id
} 
Mahasiswa di perguruan tinggi membutuhkan kemampuan untuk secara mandiri mengarahkan dirinya dalam belajar, atau menstransformasi kemampuan mental ke dalam performa akademik atau keterampilan yang terkait dengan tugastugasnya. Ini dikenal dengan proses belajar berdasar regulasi diri (Zimmerman, 2008). Proses belajar seperti ini sangat penting bagi mahasiswa, khususnya dalam konteks pembelajaran berpusat pada mahasiswa (student centered approach).

Zimmerman (2002) berpendapat bahwa belajar berdasar regulasi diri adalah penting karena fungsi utama pendidikan adalah berkembangnya keterampilan belajar seumur hidup. Pendapat yang sama juga dinyatakan oleh Ifenthaler (2012), bahwa regulasi diri dalam belajar dianggap sebagai salah satu keterampilan yang sangat penting dan dibutuhkan untuk proses belajar sepanjang masa, karena sesuai dengan tujuan utama pendidikan tinggi yaitu menghasilkan pebelajar seumur hidup (lifelong learners). Mahasiswa yang belajar berdasar regulasi diri menurut Villach dan Lianos (2007) akan mampu bersaing dalam era perkembangan pengetahuan yang pesat dan keterampilan dalam karir mereka, karena mahasiswa yang demikian dikarakteristikkan sebagai pebelajar yang strategik, mampu mengontrol dan bertanggung jawab terhadap pembelajarannya (Arabzadeh, Kadivar, \& Dlavar, 2012), memiliki motivasi yang superior, metode belajar yang adaptif, sukses secara akademik, dan memandang masa depannya secara optimis (Zimmerman, 2002). Pentingnya makna belajar berdasar regulasi telah menjadikannya sebagai salah satu fokus utama dalam penelitian psikologi pendidikan (Boekaerts, Pintrich, \& Zeidner, 2000).
Dukungan terhadap belajar berdasar regulasi diri mahasiswa di perguruan tinggi merupakan kepentingan pendidikan yang harus terakomodasi di dalam kurikulum. Dimana mahasiswa tidak hanya dituntut untuk mencapai penguasaan akademik, akan tetapi juga menuntut tercapainya kemampuan untuk menguasai hakikat belajar secara berkelanjutan yang dapat diperoleh melalui kemandirian dalam belajar mencakup keterampilan mengarahkan atau meregulasi diri. Dengan demikian, pencapaian kedua hal tersebut adalah perwujudan implementasi kurikulum yang utuh (Pusat Penelitian UPI, 2010).

Namun pada kenyatannya, menurut Valle, dkk. (2008) sebagian besar dari peserta didik yang mencapai studi yang lebih tinggi tidak cukup siap untuk menghadapi tuntutan atau tantangan di tingkat universitas karena mereka tidak mampu untuk meregulasi diri dalam proses belajar. Pernyataan ini didukung oleh fakta di lapangan sebagaimana yang dilaporkan oleh Ashar (Pembantu Dekan I Fakultas Ekonomi dan Bisnis Universitas Brawijaya), bahwa pada tahun 2012, 70 mahasiswa drop out dengan jumlah mahasiswa tahun pertama yang paling banyak (33 orang). Menurut Ashar (2012), penyebab permasalahan ini adalah faktor internal mahasiswa, yaitu minat belajar yang rendah, kegagalan beradaptasi secara akademik dan sosial, serta kurangnya kemampuan mereka dalam mengarahkan diri atau belajar mandiri. Hal yang sama juga terjadi di UIN Makassar, dimana pada tahun 2014, sekitar tujuh ratus lebih mahasiswa drop out. Salah satu alasan pemutusan studi mereka adalah ketidakmampuan mereka memenuhi tuntutan akademik yaitu, mencapai standar minimal indeks prestasi akademik yang ditetapkan setelah menghabiskan masa 
studi dua semester (Biro Akademik UIN Makassar, 2014).

Temuan penelitian sebelumnya juga dilaporkan oleh Peverly, Brobst, Graham, dan Shaw (2003) bahwa mahasiswa psikologi masih menunjukkan belajar berdasar regulasi diri yang rendah. Penelitian awal juga dilakukan peneliti pada tahun 2014 dan menemukan bahwa mahasiswa Fakultas Tarbiyah dan Keguruan UIN Makassar belum menunjukkan secara optimal belajar berdasar regulasi diri.

Pengembangan kemampuan regulasi diri sebenarnya bukan saja karena merupakan prasyarat keberhasilan kesuksesan belajar individu, akan tetapi yang terpenting adalah bahwa regulasi diri pada dasarnya adalah sifat manusia yang khas dan sangat adaptif yang memungkinkannya untuk mengganti dan mengubah respon mereka, termasuk mengubah diri sehingga memenuhi standar sosial dan yang lainnya. Seperti yang dijelaskan oleh Bandura (1986) bahwa teori sosial kognitif beranggapan bahwa manusia tidak hanya dibentuk dan diarahkan oleh lingkungan eksternalnya, akan tetapi mereka memiliki potensi untuk mengorganisasikan diri, proaktif, dapat merefleksikan dan meregulasi diri. Manusia memiliki kekuatan untuk memengaruhi tindakan mereka sendiri untuk menghasilkan hasil tertentu.

Untuk meningkatkan tingkat belajar berdasar regulasi mahasiswa, perlu mengivestigasi faktor yang berkontribusi. Hal ini menurut Sierens, dkk. (2009) dikarenakan belajar berdasar regulasi diri tidak terjadi secara otomatis dan tidak mudah diinduksi. Meskipun regulasi diri telah menjadi sifat khas manusia, akan tetapi pada kenyataannya sebagian manusia mampu meregulasi diri dengan baik dan sebagian lainnya kurang menunjukkan perilaku tersebut. Winne (2005) menyatakan bahwa jika belajar berdasar regulasi diri itu sifatnya "ubiquitous" atau ada dimana-mana atau dimiliki setiap orang, maka mengapa tidak semua individu sukses menunjukkan perilaku tersebut.

Temuan hasil penelitian mengindikasikan bahwa belajar berdasar regulasi diri ditentukan oleh orientasi motivasi dan strategi yang digunakan. Sebagaimana yang diyatakan oleh Arabzadeh, dkk. (2012) bahwa umumnya, belajar berdasar regulasi diri dipandang sebagai kombinasi dari keterampilan dan kemauan. Keterampilan mengacu kepada penggunaan strategi kognitif dan metakognitif yang mencakup penetapan tujuan, perencanaan dan pengorganisasian belajar, monitor diri, evaluasi diri, manajemen waktu, dan sumber daya. Sedangkan keinginan mengacu kepada orientasi motivasi individu dalam hal tujuan, nilai, dan pengharapan. Oleh karena itu, variasi tingkat belajar berdasar regulasi diri mahasiswa sebenarnya menunjukkan isyarat adanya perbedaan pada kondisi motivasi dan strategi mereka. Selain itu, peran lingkungan juga sangat penting dalam memfasilitasi konteks belajar yang mendukung motivasi yang optimal yang mengarahkan kepada keterlibatan yang tinggi dalam belajar berdasar regulasi diri.

Bukti empiris dari temuan hasil penelitian sebelumnya, menunjukkan bahwa ada korelasi antara kepuasan kebutuhan dasar psikologis dengan belajar berdasar regulasi diri (Sungur \& Gungoren, 2009; Jang, Reeve, Ryan \& Kim, 2009). Demikian pula, adopsi orientasi tujuan mastery approach berkorelasi dengan belajar berdasar regulasi (Pintrich \& De Groot, 1990; Pintrich, 1999; Somuncuoglu \& Yildirim, 1999; Neuvile, Frenay, \& Bougeis, 2007; Sadeghy \& Mansouri, 2014), dan belajar berdasar regulasi diri siswa dengan orientasi tujuan mastery approach lebih tinggi dibandingkan dengan siswa yang 
mengadopsi orientasi tujuan performansi (Susetyo dan Kumara, 2012). Dengan mempertimbangkan karakteristik individu dengan kedua variabel ini yang menfasilitasi prasyarat untuk belajar berdasar regulasi yang baik, maka penelitian ini bertujuan untuk menginvestigasi peranan kedua variabel independen ini sebagai prediktor belajar berdasar regulasi diri. Adapun rumusan masalah penelitian ini adalah: apakah kepuasan kebutuhan dasar psikologis dan orientasi tujuan mastery approach secara bersama-sama dapat secara signifikan memprediksi perilaku belajar berdasar regulasi diri mahasiswa?

Untuk memahami kerangka teoritis penelitian ini, berikut adalah penjelasan setiap variabel dan keterkaitan antara variabel independen (kepuasan kebutuhan dasar psikologis dan orientasi tujuan mastery approach) dengan variabel dependen (belajar berdasar regulasi diri).

\section{Belajar berdasar regulasi diri}

Belajar berdasar regulasi diri mengacu kepada menghasilkan pemikiran sendiri, perasaan, dan tindakan yang terencana dan dengan secara siklus diadaptasikan dengan pencapaian tujuan personal (Zimmerman, 2000). Belajar berdasar regulasi diri merupakan suatu proses yang aktif dan konstruktif dimana peserta didik menetapkan tujuan belajar mereka dan kemudian berusaha untuk memantau, mengatur, dan mengontrol kognisi, motivasi, dan perilaku, dibimbing dan dibatasi oleh tujuan, dan fitur kontekstual dalam lingkungan (Pintrich, 2000).

Definisi belajar berdasar regulasi yang dikemukakan oleh Pintrich (2000) didasarkan pada empat asumsi yang kemudian menjadi karakteristik belajar berdasar regulasi diri. Asumsi-asumsi tersebut adalah bahwa individu dalam belajar berdasar regulasi diri; (1) Dipandang sebagai partisipan aktif dalam pembelajaran; (2), Memiliki potensi untuk memonitor, mengontrol, dan meregulasi banyak aspek, yaitu kognisi, memengaruhi, perilaku, dan konteks; (3), Menentukan berbagai macam tujuan atau standar sebagai pembanding untuk menentukan apakah mereka harus melanjutkan atau melakukan beberapa perubahan dalam pembelajaran mereka; dan (4) Bahwa kegiatan belajar berdasar regulasi diri adalah mediator antara karakteristik individu dan kontekstual (Pintrich, 2000).

Belajar berdasar regulasi diri didasarkan pada teori sosial kognitif yang berasumsi bahwa belajar berdasar regulasi diri dapat dijelaskan melalui hubungan triadik resiprokal antara personal, perilaku dan lingkungan (Bandura, 1986). Menurut Zimmerman (1989), esensi dari formulasi triadik Bandura ini adalah bahwa perilaku adalah produk dari sumber pengaruh yang bersifat internal dan eksternal. Oleh karena itu, kunci utama belajar berdasar regulasi diri adalah saling ketergantungan antara peran lingkungan dan pengaruh diri (Zimmerman, 2000).

Model belajar berdasar regulasi diri yang digunakan dalam penelitian ini didasarkan pada model yang dikemukakan oleh Pintrich (2004) bahwa ketika mahasiswa meregulasi diri dalam belajar, mereka menjalani empat fase siklus (fase forethought, perencanaan, dan aktivasi, fase monitoring, fase kontrol, dan fase refleksi). Selain itu, mahasiswa juga dapat mengatur dirinya sendiri dalam empat area regulasi (kognitif, afek, perilaku, dan konteks). Karena fokus penelitian ini hanya pada tiga aspek regulasi yaitu kognitif, perilaku, dan konteks dan mencoba untuk menginvestigasi bagaimana pengaruh orientasi motivasi mahasiswa (berdasarkan teori determinasi diri dan teori orientasi tujuan) mengarahkan mereka 
untuk terlibat dalam menggunakan strategi adaptif pada tiga area regulasi tersebut. Oleh karena itu, aspek belajar berdasar regulasi diri yang diukur adalah aspek kognitif, perilaku, dan konteks.

\section{Kepuasan kebutuhan dasar psikologis}

Kepuasan kebutuhan dasar psikologis adalah bagian dari teori determinasi diri (sebuah teori motivasi) yang menpostulatkan bahwa semua individu tidak peduli usia, gender, status ekonomi, negara, latar belakang budaya memiliki tendensi inheren untuk berkembang (seperti motivasi intrinsik, keingintahuan, dan kebutuhan dasar psikologis), dan menjadi dasar motivasi keterlibatan individu di dalam pembelajaran dengan kualitas yang tinggi dan keberfungsian positif di sekolah (Reeve, 2012).

Keunikan teori determinasi diri yaitu penekanannya pada identifikasi, vitalisasi, dan peningkatan sumber motivasi yang sudah ada dalam diri peserta didik yang bersifat universal (seperti kebutuhan dasar psikologis, keingintahuan). Oleh karena itu, tugas instruksional didesain berdasarkan asumsi tersebut dan tujuannya adalah untuk meningkatkan keterlibatan yang tinggi dalam pembelajaran (Reeve \& Halusic, 2009).

Menurut Keblawi (2006), teori ini menawarkan pandangan yang menarik tentang motivasi, yaitu daripada berfokus pada bagaimana pembelajar memotivasi peserta didik di dalam kelas, teori ini lebih berfokus pada bagaimana pembelajar menciptakan kondisi di mana peserta didik dapat memotivasi diri sendiri. Ini berarti bahwa teori ini mencoba untuk mengidentifikasi sumber-sumber motivasi dalam diri peserta didik dan memberikan rekomendasi tentang bagaimana pembelajar meningkatkan, dan memvitalisasi sumber-sumber motivasi tersebut selama pembelajaran dengan tujuan untuk memfasilitasi tingkat kualitas keterlibatan yang tinggi (Niemiec \& Ryan, 2009).

Reeve (2012) menyatakan bahwa ketiga kebutuhan dasar psikologis adalah merupakan sumber tendensi motivasi intrinsik proaktif yang inheren dan mengarahkan individu untuk mengeksplorasi, dan untuk belajar. Manusia berfungsi dan berkembang secara efektif sebagai hasil dari usaha lingkungan sosial dan kapasitasnya untuk memenuhi kepuasan kebutuhan dasar psikologis individu. Teori kebutuhan dasar psikologis menjelaskan bahwa keterlibatan aktif dan pasif individu dalam belajar terkait dengan pemenuhan kepuasan kebutuhan dasar psikologis ini. Ini berarti bahwa kepuasan ketiga kebutuhan ini mempromosikan keterlibatan academik dan prestasi belajar yang baik. Sebaliknya, jika tidak terpuasakan akan menghasilkan ketidakterlibatan secara akademik dan prestasi belajar yang rendah (Niemic \& Ryan, 2009).

Premis utama teori ini adalah bahwa kebutuhan dasar harus diakomodasi agar individu termotivasi untuk bertindak (Guay, Ratelle, \& Chanel, 2008). Hasil penelitian menunjukkan bahwa jika terpuaskan, mahasiswa akan termotivasi untuk menggunakan pendekatan belajar mendalam dan penurunan penggunaan strategi avoidan. Sebaliknya, jika tidak terpuaskan akan mengarahkan mahasiswa menggunakan pendekatan belajar surface, strategi belajar avoidan, dan penurunan pada pencapaian hasil belajar (Betoret \& Artiga, 2011). Selain bukti empiris ini, Jang, dkk. (2009) melaporkan bahwa: (1) Dukungan terhadap otonomi, kompetensi, dan keterkaitan merupakan dasar dari kepuasan yang tinggi dalam pengalaman belajar siswa sekolah menengah atas di Korea. Sebaliknya, siswa yang tidak didu- 
kung mengalami kepuasan belajar yang rendah; (2) Kepuasan kebutuhan dasar psikologis berkorelasi dengan hasil belajar siswa yang memuaskan. Selain itu, Lim dan Wang (2009) juga melaporkan pentingnya persepsi siswa terhadap dukungan otonomi dalam meningkatkan determinasi diri dalam meregulasi perilaku dalam belajar.

Kebutuhan dasar psikologis memiliki tiga komponen, yaitu: pertama, kebutuhan otonomi, yang dikonseptualisasikan sebagai pengalaman merasakan adanya pilihan, dukungan, dan kemauan berkaitan dengan memulai, memelihara, dan mengakhiri keterlibatan perilaku (Niemic, Lynch, Vansteenkistec, Bernstein, Decia, \& Ryan, 2006). Otonomi bermakna bahwa individu adalah inisiator dan sumber dari perilakunya (Guay, dkk., 2008). Filak dan Sheldon (2003) juga menyatakan bahwa mendukung otonomi berarti mengambil perspektif mahasiswa, memberikan pilihan, dan memberikan alasan jika tidak ada kemungkinan pilihan. Hasil penelitian menunjukkan bahwa dukungan terhadap kebutuhan otonomi meningkatan motivasi intrinsik, memandang diri kompeten, dan harga diri dari waktu ke waktu (Niemic \& Ryan, 2009).

Kedua adalah kebutuhan kompetensi yang didefinisikan sebagai keinginan yang melekat pada individu untuk merasa efektif dalam berinteraksi dengan lingkungan, mencerminkan kebutuhan untuk melatih kemampuan, dan mencari tantangan yang optimal (Reeve \& Sickenius, 1994; Deci \& Ryan, 2000). Kebutuhan kompetensi berkaitan dengan keyakinan individu untuk melakukan tugas tertentu secara efisien dan efektif (Guay, dkk, 2008). Menurut Deci dan Ryan (2000), indikator kepuasan kebutuhan ini adalah ketika individu merasa bahwa mereka memiliki cukup keterampilan untuk mengerjakan tugas dan mencapai tujuan dengan kemampuan terbaiknya. Filak dan Sheldon (2003) menyatakan bahwa istilah kompetensi terkait dengan efikasi diri. Mendukung kebutuhan ini berarti memberi keyakinan mahasiswa terhadap kemampuannya untuk mengambil tantangan. Niemic dan Ryan (2009) menyatakan bahwa kebutuhan ini dapat didukung dengan memperkenalkan mereka dengan kegiatan belajar menantang yang memungkinkan mereka untuk menguji dan mengembangkan kompetensi akademik mereka.

Ketiga adalah kebutuhan keterkaitan (need for relatedness), yang didefinisikan sebagai kecenderungan yang melekat pada individu untuk merasa terhubung dengan orang lain, yaitu untuk menjadi anggota kelompok, untuk dicintai, dipeduli, dan diperhatikan (Baumeister \& Leary, 1995), mengacu pada kehangatan dan perhatian yang diterima dari interaksi dengan orang lain, sehingga menghasilkan rasa memiliki (Niemic, dkk., 2006), melibatkan kebutuhan untuk terkoneksi secara aman dengan orang lain dalam lingkungannya dan mengalami perasaan layak untuk disayangi dan di hargai (Osterman, 2000). Dalam konteks hubungan antara guru dan murid, dukungan terhadap kebutuhan keterkaitan memberikan rasa penerimaan, dihargai, diperhatikan dan rasa kebersamaan (Filak \& Sheldon, 2003). Furrer dan Skinner (2003) mengatakan bahwa kebutuhan keterkaitan memiliki peranan penting terhadap motivasi dan performa siswa. Siswa yang melaporkan perasaan keterkaitan yang tinggi menunjukkan keterlibatan emosional dan behavioral di sekolah. Deci, Vallerand, Pelletier, dan Ryan (1991) memprediksikan bahwa jika kebutuhan keterkaitan ini tidak terpuaskan dalam konteks belajar, maka motivasi mereka akan menurun, perkembangan 
yang terhambat, perasaan teralienasi dan performa yang buruk.

\section{Orientasi tujuan mastery approach}

Teori orientasi tujuan muncul sebagai arah baru dalam penelitian motivasi (Dweck \& Legget, 1988). Teori ini berkembang dalam kerangka teori sosial kognitif dan merupakan salah satu konstruks motivasi yang terkait dengan alasan atau tujuan individu terlibat dalam sebuah tugas atau mencoba menjawab pertanyaan "Why am I doing this task?" (Miltiadou \& Savenye, 2003). Teori sosial kognitif berasumsi bahwa umumnya tindakan manusia diarahkan oleh tujuan.

Orientasi tujuan terkait dengan persepsi terhadap penyebab mengapa individu tertarik atau terlibat dalam mempelajari sebuah tugas (Marcou \& Philippou, 2005), atau terkait dengan tujuan untuk terlibat dalam perilaku pencapaian (Ames, 1992). Oleh karena itu, menurut teori orientasi tujuan, ada korelasi antara performa individu dan orientasi tujuannya. Orientasi tujuan merupakan pola keyakinan, atribusi, dan nilai yang diadopsi individu yang terefleksi dalam perilaku pencapaiannya (Elliot, 2005), atau menurut Pintrich dan Schunk (1996), orientasi tujuan merefleksikan sebuah jenis standar dimana individu akan menilai keyakinannya seperti atribusi, afek, demikian pula performa aktual dan perilaku. Dweck dan Legget, (1988) menyatakan bahwa tujuan yang dikejar individu menciptakan kerangka dimana mereka menginterpretasi dan bereaksi terhadap peristiwa, secara khusus dalam domain pencapaian intelektual.

Teori orientasi tujuan berbeda dengan teori tujuan lainnya. Jika teori tujuan lainnya membahas perilaku manusia secara luas, teori ini dikembangkan dalam konteks sekolah untuk memberikan penjelasan terhadap perilaku pencapaian, atau menjelaskan belajar dan performa siswa dalam tugas akademik di sekolah. Oleh karena itu, teori ini merupakan teori tujuan yang paling relevan dan dapat diaplikasikan untuk memahami dan meningkatkan proses belajar mengajar (Pintrich \& Schunk, 1996). Livengood (1992) menyatakan bahwa salah satu cara untuk menentukan mahasiswa mana yang lebih mungkin mengerahkan upaya yang diperlukan di perguruan tinggi untuk sukses adalah dengan mengetahui tujuan motivasional mahasiswa dan keyakinan tentang usaha dan kemampuannya.

Teori orientasi tujuan merupakan salah satu teori yang paling menonjol dan aplikatif yang digunakan untuk memahami motivasi akademik peserta didik (Pintrich \& Schunk, 1996), dan menjelaskan proses motivasi sebagai faktor psikologis (selain kemampuan) yang menentukan seberapa efektif individu menggunakan keterampilan (Dweck, 1986). Teori pencapaian tujuan menyatakan bahwa individu terlibat dalam kegiatan akademik untuk memenuhi standar yang berbeda. Dalam mengevaluasi kompetensi, menurut Mattern (2005), sebagian mahasiswa termotivasi untuk mendapatkan nilai tinggi untuk menunjukkan kecerdasannya, dan sebagian lainnya lebih mementingkan pemahaman terhadap materi dan meningkatkan kemampuan. Dalam mengevaluasi kemampuan, individu menggunakan standar yang berbeda. Menurut Mattern (2005), sebagian mahasiswa termotivasi untuk mendapatkan skor yang tinggi (kriteria normatif), dan sebagian lainnya termotivasi untuk meningkatkan kemampuan (kriteria abosolut). Adapun menurut dimensi nilai, sebagian mahasiswa mengerjakan tugas karena memandangnya sebagai sesuatu yang positif dan dibutuh- 
kan, sedangkan sebagian lainnya menunjukkan perilaku menghindari karena memandang tugas sebagai sesuatu yang negatif dan tidak diinginkan (Elliot \& McGregor, 2001). Berdasarkan kedua dimensi ini maka Elliot dan McGregor (2001) dalam model 2 X 2 orientasi tujuannya mendefinisikan orientasi tujuan mastery approach sebagai orientasi tujuan dengan standar absolut-interpersonal dan nilai positif (positive valence).

Berdasarkan temuan hasil penelitian, orientasi tujuan mastery approach dikarakteristikkan sebagai tujuan yang berfokus pada peningkatan keterampilan baru, pemahaman, dan penekanan pada makna personal tugas (Ames, 1992; Tapola \& Niemivirta, 2008), memiliki self-esteem yang tinggi dan usaha dipandang sebagai bagian dari belajar dan syarat kesuksesan (Tapola \& Niemivirta, 2008), memiliki preferensi terhadap tugas menantang dan mengambil risiko (Ames \& Archer, 1988; Elliot \& Dweck, 1988; Dweck \& legget, 1988), memiliki sikap positif dalam belajar (Ames \& Archer, 1988), perisisten meskipun mendapatkan kesulitan (Elliott \& Dweck, 1988), keterlibatan aktif dalam mengaplikasikan strategi belajar efektif dan pemecahan masalah, serta kesadaran terhadap bagaimana dan kapan menggunakan strategi belajar berdasar regulasi diri (Nolen, 1988; Pintrich \& De Groot, 1990; Somuncuoglu \& Yildirim, 1999; Dupeyrat \& Marine, 2005;)

Keterkaitan antara kepuasan kebutuhan dasar psikologis dan orientasi tujuan mastery approach dengan belajar berdasar regulasi diri

Teori sosial kognitif menjelaskan bahwa belajar berdasar regulasi diri didukung oleh tiga faktor (personal, perilaku, dan lingkungan) yang memiliki hubungan resiprokal (Bandura, 1986). Akan tetapi, menurut Zimmerman (1989), bahwa esensi formulasi triadik Bandura menyatakan bahwa perilaku adalah produk dari sumber pengaruh dari dalam diri dan dari luar. Sebagai contoh, sumber dari dalam diri seperti motivasi individu merupakan aspek terpenting dari belajar berdasar regulasi diri. Boekaert dan Cascallar (2006), membatasi belajar berdasar regulasi diri hanya pada strategi kognitif dan metakognitif dan mengabaikan motivasi sebagai kekuatan pengarah dalam proses belajar. Teori determinasi diri menawarkan konsep bahwa untuk dapat memberi energi yang mengarahkan perilaku individu, dapat dilakukan dengan mengakomodir kepuasan kebutuhan dasar psikologisnya yaitu otonomi, kompetensi, dan keterkaitan.

Dalam teori determinasi diri, regulasi diri dikonseptualisasikan sebagai sebuah kontinum yang bermakna bahwa individu dapat lebih atau kurang meregulasi diri terasosiasi dengan tingkat kepuasan kebutuhan dasar psikologisnya yang merupakan sumber motivasi intrinsik. Level tertinggi dari pengaturan diri melibatkan tindakan yang dilakukan karena orang merasa tertarik atau penting untuk melakukannya, dan tingkat terendah hanya karena orang tersebut merasa dipaksa oleh beberapa agen eksternal. Menurut Paris dan Paris (2001), sesuai dengan namanya belajar berdasar regulasi diri menekankan pada otonomi dan kontrol individu yang memonitor, mengarahkan, dan meregulasi tindakan untuk mencapai tujuan pemerolehan informasi, mengembangkan keahlian, dan peningkatan diri. Dengan demikian, kebutuhan otonomi mahasiswa harus dipenuhi untuk lebih dapat meregulasi diri

Teori determinasi diri mengemukakan bahwa usaha untuk mengontrol seseorang akan menguras atau menghabiskan vitalitas dan energi psikologis (Ryan \& Decy, 
2008), dan mengarah kepada rendahnya kualitas perilaku dan bahkan ketidakterlibatan (disengagement), karena ketika terkontrol, orang hanya akan cenderung melakukan yang diperintahkan saja (Ryan \& Deci, 2006). Akan tetapi, ini tidak berlaku bagi regulasi diri yang otonomi. Ini berarti bahwa bentuk-bentuk otonomi atau benar-benar berkehendak dalam regulasi diri tidak akan menghasilkan deplesi ego. Selain itu, mereka memprediksi bahwa kepuasan yang berhubungan dengan kebutuhan dasar diri seharusnya memelihara atau meningkatkan vitalitas dan mempertahankan kapasitas regulasi diri. Oleh karena itu, teori determinasi diri secara khusus memprediksi bahwa kegiatan yang memenuhi kepuasan terhadap kebutuhan dasar psikologis (otonomi, kompetensi, dan keterkaitan) akan menghasilkan pemeliharaan energi atau peningkatan keterlibatan.

Zimmerman (2002) menyatakan bahwa meskipun hubungan kemandirian untuk sukses dalam hidup telah diakui secara luas, sebagian besar peserta didik masih berjuang untuk mencapai disiplin diri dalam metode belajar mereka. Penelitian kontemporer mengungkapkan bahwa kualitas motivasi diri individu yang meregulasi diri dalam belajar bergantung kepada beberapa keyakinan yang mendasari, termasuk efikasi diri dan minat intrinsik. Zimmerman dan Kitsantas (2005) menyatakan bahwa karena regulasi diri melibatkan inisiasi diri dan ketekunan, maka keyakinan motivasi diri menjadi sangat penting. Filak dan Sheldon (2003) menyatakan bahwa kepuasan kebutuhan kompetensi dekat dengan efikasi diri dan dapat terlihat ketika seseorang mengerjakan tugas yang menantang dan pemberian umpan balik positif. Pernyataan ini didukung oleh hasil penelitian yang dilakukan oleh Deci (Deci, dkk., 1996) dalam sebuah eksperimen yang hasilnya menunjukkan bahwa ketika mahasiswa diberitahu bahwa mereka melakukan dengan baik pada kegiatan memecahkan teka-teki, mereka menunjukkan bukti keterlibatan yang lebih besar dibandingkan mahasiswa yang tidak menerima umpan balik. Dengan demikian, mendukung kebutuhan kompetensi melalui tugas yang menantang dan umpan balik positif berarti memberi pengalaman kepada mahasiswa untuk meyakini kemampuannya.

Belajar berdasar regulasi diri juga merupakan bentuk interaksi sosial khususnya dalam area regulasi konteks. Oleh karena itu, kebutuhan keterkaitan menjadi sangat penting. Ryan, Stiller, dan Lynch (1994) menemukan bahwa siswa yang merasa aman dengan orang tua dan guru mereka, dan dapat meminta bantuan dari keduanya ketika mendapatkan masalah cenderung beradaptasi lebih positif dengan kegagalan akademik, lebih otonomi dalam meregulasi perilaku mereka di sekolah, lebih terlibat dalam belajar, dan merasa lebih baik terhadap diri mereka. Payakachat, dkk. (2013) menemukan bahwa staf pengajar yang dipersepsikan mahasiswa menghargai mahasiswanya, bersedia berbagi, tidak menjaga jarak, dan ramah akan meningkatkan perilaku mahasiswa dalam mencari bantuan. Dukungan sosial ini merupakan bentuk pemuasan kebutuhan keterkaitan yang dimaknai sebagai perasaan menjadi bagian dari komunitas (Baumeister \& Leary, 1995), rasa memiliki (Niemic, dkk., 2006), terkoneksi dengan yang lain (Osterman, 2000), rasa penerimaan, dihargai, diperhatikan dan rasa kebersamaan dalam konteks hubungan pendidik dan peserta didik (Filak \& Sheldon, 2003).

Newman (2002) menjelaskan bahwa salah satu tantangan dalam belajar 
berdasar regulasi diri adalah keterlibatan atau persistensi yang tetap ketika menghadapi masalah dan potensi kegagalan. Oleh karena itu, dia menyarankan bahwa ketika seorang mahasiswa mengalami hal tersebut, penting bagi mereka untuk dapat berinisiatif mencari bantuan dari pada menyerah. Akan tetapi yang menjadi pertanyaan adalah mengapa mahasiswa tidak melakukan hal tersebut. Ada dua faktor yang dianggap berpengaruh terhadap perilaku mencari bantuan ini, yaitu faktor personal seperti kurangnya kompetensi untuk mengembangkan strategi adaptif dalam mencari bantuan, dan faktor lingkungan sosial seperti tidak adanya dukungan dari pendidik dan teman.

Selain kepuasan kebutuhan dasar psikologis, orientasi tujuan penguasan juga erat kaitannya dengan orientasi tujuan mastery approach. Pintrich (1999) mengungkapkan bahwa orientasi tujuan sangat sesuai dengan teori belajar berdasar regulasi diri. Asumsinya adalah bahwa untuk dapat meregulasi diri dalam belajar, yaitu meregulasi performa, dan perilaku, individu harus memiliki tujuan, standar atau kriteria sebagai pembanding terhadap kemajuan yang dicapai. Selain itu, teori orientasi tujuan memberikan penjelasan bahwa adopsi salah satu orientasi tujuan akan terkait dengan strategi belajar berdasar regulasi diri yang digunakan. Pintrich (1999) mengemukakan bahwa ada korelasi yang kuat antara tujuan yang berbeda dengan regulasi diri. Individu dengan orientasi tujuan mastery approach berorientasi pada peningkatan diri. Dengan orientasi tujuan ini, akan mendorong individu untuk menunjukkan perilaku adaptif dengan menggunakan strategi efektif sebagai usaha pencapaian tujuan. Teori orientasi tujuan atau disebut juga teori pencapaian tujuan (achievement goal theory) merupakan salah satu teori motivasi yang telah membuktikan adanya korelasi antara orientasi motivasi individu dengan belajar berdasar regulasi diri.

Korelasi yang kuat dan positif antara orientasi tujuan mastery aproach dengan strategi belajar berdasar regulasi diri didukung oleh beberapa penelitian yang dilakukan pada semua tingkatan pendidikan. Sebagai contoh, penelitian Meece, dkk. (1988) menemukan bahwa orientasi tujuan mastery approach siswa sekolah dasar memiliki hubungan dengan keterlibatan kognitif yang aktif dan penggunaan pada strategi regulasi diri. Ames dan Archer (1988) juga melaporkan bahwa siswa sekolah menengah yang beorientasi tujuan ini lebih menggunakan strategi yang efektif, menginginkan tugas yang menantang, memiliki sikap positif terhadap pembelajaran di kelas, dan memiliki keyakinan yang kuat bahwa kesuksesan berasal dari usaha seseorang. Mereka menyimpulkan bahwa orientasi tujuan dapat memfasilitasi terpeliharanya polapola motivasi adaptif, hanya jika tujuan penguasaan diadopsi oleh siswa. Somuncuoglu dan Yildirim (1999) menemukan bahwa mahasiswa dengan orientasi tujuan penguasaan terasosiasi dengan penggunaan strategi belajar kognitif mendalam dan strategi metakognisi. Selanjutnya, Neufille, dkk. (2007) menemukan bahwa ada korelasi antara orientasi tujuan penguasaan dengan komponen belajar berdasar regulasi diri pada mahasiswa psikologi di Belgia.

Orientasi tujuan mastery approach juga terbukti memiliki keterkaitan dengan belajar berdasar regulasi diri pada aspek strategi regulasi perilaku, yaitu adanya korelasi antara orientasi tujuan ini dengan strategi mencari bantuan yang bersifat adaptif (adaptif help-seeking). Hasil penelitian Newman dan Schwager (1995) menunjukkan bahwa siswa dengan orien- 
tasi tujuan penguasaan, ketika melakukan kesalahan, timbul keinginan yang besar untuk mengkonfirmasi atau menjadikannya sebagai umpan balik atas apa yang telah mereka lakukan, memandang kesalahan sebagai sesuatu yang natural, dan cenderung menunjukkan strategi mencari bantuan yang adaptif dibanding dengan siswa dengan orientasi tujuan lainnya.

Pintrich dan De Groot (1990) menyatakan bahwa orientasi tujuan mastery approach terasosiasi dengan motivasi adaptif. Mereka melaporkan bahwa orientasi motivasional individu memengaruhi belajar berdasar regulasi diri. Hasil penelitian lainnya juga dilaporkan oleh Elliot, dkk. (1999), demikian pula Moller dan Elliot (2006), bahwa tujuan mastery approach memprediksi penggunaan strategi belajar mendalam (deep learning strategies), dan tidak berkorelasi dengan disorganisasi, kekhawatiran dan emosionalitas, dan kecemasan terhadap ujian. Profil motivasi adaptif seperti ini tentu saja dibutuhkan dalam belajar berdasar regulasi diri.

Berdasarkan kerangka teori penelitian yang diuraikan di atas, dibuat hipotesis penelitian, yaitu kepuasan kebutuhan dasar psikologis dan orientasi tujuan mastery approach secara bersama-sama dapat memprediksi belajar berdasar regulasi diri.

\section{Metode}

\section{Subjek penelitian}

Subjek penelitian ini berjumlah 240 mahasiswa S1 dari delapan Program Studi yang berbeda pada Fakultas Tarbiyah dan Keguruan Universitas Islam Negeri Makassar dan berada pada semester III, V, dan VII tahun akademik 2014/2015. Subjek penelitian ini terdiri atas $160(66,7 \%)$ perempuan dan $80 \quad(33,3 \%)$ laki-laki, berusia antara $18 \mathrm{~s} / \mathrm{d} 28$ tahun.

\section{Instrumen penelitian}

Skala belajar berdasar regulasi diri

Skala belajar berdasar regulasi diri merupakan self-report yang ini terdiri atas 30 aitem dan menggunakan skala Likert yang terdiri atas empat pilihan. Skala ini adalah hasil adaptasi dari The Motivated Strategies for Learning Questionnaire (MSLQ) yang dikembangkan secara formal oleh McKeachie dan Pintrich pada tahun 1986 di Universitas Michigan. Skala ini didesain untuk mengukur orientasi motivasi dan penggunaan strategi belajar mahasiswa (Pintrich, Smith, Garcia, \& McKeachie, 1991). Skala ini telah secara luas digunakan dalam berbagai penelitian dan diberbagai negara dan telah terbukti memiliki validitas dan realibilitas yang baik (Pintrich, dkk., 1991; Artino, 2005). Sesuai dengan definisi operasional penelitian ini, skala ini mengukur belajar berdasar regulasi diri pada area regulasi kognitif, perilaku dan konteks. Komponen strategi regulasi kognitif meliputi strategi mengulang, organisasi, elaborasi, berfikir kritis, dan regulasi diri metakognisi; strategi regulasi perilaku meliputi regulasi usaha, kelola waktu dan mencari bantuan; dan strategi regulasi konteks yang meliputi belajar dengan teman/kelompok dan kelola lingkungan. Berdasar uji coba yang peneliti lakukan, skala ini memiliki koefisien Alpha Cronbach sebesar 0,896.

\section{Skala Kepuasan Kebutuhan Dasar Psikologis}

Skala kepuasan kebutuhan dasar psikologis yang digunakan terdiri atas tiga komponen yaitu otonomi, kompetensi dan keterkaitan. Skala ini adalah self-report yang menggunakan skala Likert dengan empat pilihan. Pengembangan aitem skala 
ini merupakan modifikasi dari aitem skala yang dikembangkan oleh Ilardi, Leone, Kasser, dan Ryan (1993), Broeck, Vansteenkiste, Witte, Soenens, \&, Lens (2010), dan Batoret dan Artiga (2011). Adapun realibilitas skala ini setelah diuji coba adalah 0,927

\section{Skala orientasi tujuan mastery approach}

Skala orientasi tujuan mastery approach dalam penelitian ini menggunakan dimensi yang ditawarkan oleh Pintrich and Schunk (1996) yang terdiri atas dua dimensi. Pertama, dimensi tujuan yang mencakup sub dimensi pandangan terhadap sukses, padangan terhadap tugas, alasan usaha, pandangan terhadap kesalahan, dan kriteria evaluasi. Kedua, dimensi outcome yaitu atribusi, afek, kognisi, dan perilaku. Dalam mengembangkan skala ini, beberapa aitem yang digunakan juga diambil dari Patterns of Adaptif Learning Scale (Midgley, Kaplan, Middleton, Maehr, Urdan, \& Anderman, 1998), dan Darwati (2003) yang relevan dengan dimensi Pintrich and Schunk (1996). Realibilitas skala ini setelah diuji coba adalah 0,939 .

\section{H a s i 1}

Uji hipotesis penelitian ini dilakukan dengan menggunakan teknik analisis regresi linier berganda, yaitu suatu cara dilakukan untuk memprediksi outcome variabel dari beberapa variabel prediktor (Field, 2009). Penggunaan analisis regresi berganda dalam penelitian ini bertujuan untuk menguji tingkat prediksi secara bersama-sama kedua variabel independen (kepuasan kebutuhan dasar psikologis dan orientasi tujuan mastery approach) terhadap variabel dependen (belajar berdasar regulasi diri). Berdasarkan hasil analisis uji regresi menggunakan program SPSS, didapatkan nilai $F_{\text {regresi }}$ sebesar 115.303 dan nilai $p<0,001$. Berdasarkan hasil uji statistik ini maka dapat disimpulkan bahwa hipotesis penelitian ini diterima dimana kepuasan kebutuhan dasar psikologis dan orientasi tujuan mastery approach secara bersama-sama dapat secara signifikan memprediksi belajar berdasar regulasi diri mahasiswa, dengan sumbangan efektif $\left(R^{2}\right)$ sebesar 0.493 atau $49.3 \%$. Selanjutnya, untuk menentukan kontribusi masingmasing variabel prediktor terhadap variabel kriterium dilakukan uji regresi parsial dan ditemukan sumbangan efektif kepuasan kebutuhan dasar psikologis sebesar $4,9 \%$ dengan nilai $p<=0,01$, dan variabel orientasi tujuan mastery approach berkontribusi sebesar $44,4 \%$ dengan nilai $p<$ 0,001 .

\section{Diskusi}

Temuan hasil penelitian ini mengindikasikan bahwa untuk mendukung atau meningkatkan belajar berdasar regulasi diri, mahasiswa perlu mengadopsi orientasi tujuan mastery approach dan memiliki kepuasan kebutuhan dasar psikologis karena keduanya secara bersama-sama memberikan sumbangan efektif yang cukup besar $(49,3 \%)$. Selain itu, tingkat belajar berdasar regulasi diri dapat digambarkan sebagai kontinum yang bermakna bahwa semakin tinggi adopsi orientasi tujuan mastery approach dan kepuasan kebutuhan dasar psikologis mahasiswa, semakin tinggi belajar berdasar regulasi dirinya.

Jika melihat besarnya kontribusi secara parsial dari variabel orientasi tujuan mastery approach sebagai salah satu prediktor dalam model regresi penelitian ini dapat dijelaskan dengan merujuk kepada apa yang dikemukakan oleh Pintrich (2000) bahwa meskipun model- 
model belajar berdasar regulasi diri memiliki perbedaan dalam hal konstruk akan tetapi semua memiliki kesamaan asumsi diantaranya adalah asumsi tujuan, kriteria, atau standar. Ini bermakna bahwa semua model tersebut mengasumsikan adanya tujuan, kriteria atau standar yang menjadi acuan atau pembanding ketika melakukan evaluasi dalam proses regulasi diri.

Pintrich (1999) mengemukakan relevansi tujuan dengan belajar berdasar regulasi diri dan peranan pentingnya dalam setiap fasenya. Dia menjelaskan bahwa untuk dapat belajar berdasar regulasi diri, mahasiswa seharusnya membuat tujuan, kriteria atau standar (fase forethought dan perencanaan) yang dijadikan sebagai pembanding terhadap apa yang telah dicapai (fase monitoring), atau untuk menentukan apakah proses belajar harus dilanjutkan atau beberapa perubahan harus dilakukan untuk dapat mencapai tujuan yang telah ditetapkan dengan meregulasi kognisi, motivasi, atau perilaku (fase kontrol). Ketiga kegiatan ini merupakan bagian dari fase-fase yang penting dalam belajar berdasar regulasi diri (Zimmerman, 2000; Pintrich, 2004).

Jika asumsi model regulasi ini dikaitkan dengan variabel orientasi tujuan, maka jelas terlihat adanya kesamaan pandangan dimana teori orientasi tujuan juga memandang bahwa manusia diarahkan oleh adanya tujuan yang dimaknai sebagai alasan seseorang untuk mencapai tujuan tertentu dan menjadi standar pencapaian. Selanjutnya, teori orientasi tujuan ini lebih jauh menjelaskan bahwa manusia dapat mengadopsi orientasi tujuan yang berbeda dan akan menentukan outcome motivasi, strategi kognitif, dan perilakunya yang akan tergambar dalam proses regulasi dirinya dalam belajar.
Selanjutnya, perbedaan outcome motivasi, strategi kognitif, dan perilaku diakibatkan oleh adanya perbedaan karakteristik dari orientasi tujuan yang diadopsi dalam aspek pandangan terhadap usaha, tugas, kriteria kesuksesan dan kegagalan, demikian pula pada atribusi, strategi, dan perilaku. Oleh karena itu, pemilihan orientasi tujuan mastery approach sebagai prediktor dalam penelitian ini didasarkan pada karakteristiknya yaitu berorientasi pada penguasaan tugas, belajar, pemahaman, menggunakan standar absolut yaitu mengacu pada peningkatan diri, kemajuan, dan pemahaman yang mendalam terhadap tugas (Pintrich, 2000). Dengan karakteristik ini, memungkinkan individu yang mengadopsinya untuk terlibat dalam proses belajar berdasar regulasi diri yang lebih sukses sebagaimana yang ditunjukkan oleh bukti empiris hasil penelitian.

Untuk mencapai tujuan yang telah ditetapkan dalam belajar berdasar regulasi diri, dibutuhkan penggunaan strategi yang adaptif. Banyak hasil penelitian yang menunjukkan bukti empiris bahwa adopsi orientasi tujuan mastery approach terasosiasi secara kuat dengan penggunaan strategi kognitif dan metakogniitif yang adaptif (Ames \& Archer, 1988; Pintrich \& De Groot, 1990; Greene \& Miller, 1996; Somuncuoglu \& Yildirim, 1999; Dupeyrat \& Marine, 2005; Kahraman, 2011; Gurcay \& Balta, 2013; Sadeghy \& Mansoury, 2014). Selain itu, orientasi tujuan ini juga terasosiasi dengan strategi mencari bantuan yang adaptif yang sangat penting dalam area regulasi konteks belajar berdasar regulasi diri. menurut Ryan, Pintrich, dan Midgley (2001), hal ini disebabkan oleh pandangan bahwa strategi mencari bantuan penting untuk meningkatkan performa dan pemahaman. Newman dan Schwager (1995) melaporkan bahwa siswa 
yang mengadopsi orientasi tujuan ini, ketika membuat kesalahan, mereka memiliki keinginan yang kuat untuk mengkonfirmasi, atau menjadikan kesalahan sebagai umpan balik, dan menunjukkan strategi mencari bantuan. Temuan lainnya juga menunjukkan bahwa terdapat korelasi yang kuat antara orientasi tujuan ini dengan perilaku mencari bantuan yang adaptif dalam pembelajaran matematika (Darwati, 2003), dan bahkan dapat memprediksi persepsi positif dan frekuensi mencari bantuan (Butler, 2007).

Penjelasan tentang dinamika hubungan profil motivasi orientasi tujuan mastery approach dengan belajar berdasar regulasi diri adalah: pertama, keyakinan bahwa sukses terkait dengan usaha atau usaha merupakan pra-syarat sukses (Ames \& Archer, 1988; Tapola \& Niemivirta, 2008),), akan memengaruhi keyakinan kontrol, yaitu pengharapan mahasiswa bahwa mereka dapat menguasai tugas melalui usaha yang optimal. Ini juga dapat dijelaskan oleh keyakinan bahwa inteligensi bersifat malleable atau dapat dirubah melalui usaha (Dweck, 1986). Kedua, keyakinan nilai tugas, yaitu suatu bentuk apresiasi, keyakinan bahwa tugas itu menarik, dan evaluasi tentang pentingnya fungsi tugas dalam meningkatkan kompetensi (Pintrich \& De Groot, 1990). Pintrich dan Schunk (1996) juga mengkarakteristikkan orientasi tujuan mastery approach dengan persepsi bahwa sukses adalah suatu bentuk peningkatan, kemajuan, kreativitas, inovasi, dan belajar. Ketiga, aspek afektif yaitu reaksi emosional terhadap tugas. Bembenutty, McKeachie, Karabenick, dan Lin (1998) menyatakan bahwa kecemasan terhadap ujian dapat berdampak negatif terhadap penggunaan strategi memperoleh pengetahuan dan penurunan motivasi. Terkait dengan karakteristik orientasi tujuan mastery approach, Huijun, Dejun, Hongli, dan Peixia (2006) melaporkan bahwa orientasi tujuan ini tidak berkorelasi dengan kekhawatiran dan emosionalitas, dan menurut Bayrami, Yari, Khani, dan Mohammadi (2014), berkorelasi secara negatif dengan kecemasan terhadap ujian.

Hubungan positif yang ditunjukkan oleh variabel kepuasan kebutuhan dasar psikologis terhadap belajar berdasar regulasi mahasiswa dan berkontribusi terhadap peningkatan belajar berdasar regulasi diri sejalan dengan hasil penelitian sebelumnya. Sebagaimana yang dilaporkan oleh Betoret dan Artiga (2011) bahwa kepuasan kebutuhan dasar psikologis dapat meningkatkan belajar berdasar regulasi melalui penggunaan pendekatan belajar yang mendalam. Selanjutnya, efek dari pemenuhan ketiga kepuasan ini (otonomi, kompetensi, dan keterkaitan) adalah pertama, belajar berdasar regulasi diri menekankan pada otonomi dan kontrol individu (Paris \& Paris, 2001), atau bersifat autonomous dimana perilaku seseorang merupakan hasil dari determinasi diri (Deci \& Ryan, 2000). Deci, dkk. (1996) menyatakan bahwa dalam belajar berdasar regulasi diri, seseorang butuh pengalaman berkehendak, yaitu keinginan yang tidak terkontrol untuk terlibat dalam suatu tindakan atau mengerjakan sesuatu dengan dukungan penuh. Hal ini sejalan dengan penjelasan teori determinasi diri bahwa seseorang yang termotivasi secara otonomi, memiliki kehendak atau dukungan untuk bertindak (Deci \& Ryan, 2008). Salah satu hipotesis sentral teori determinasi diri menurut Guay, dkk. (2008) adalah seseorang yang belajar berdasar regulasi diri dengan motivasi yang bersifat otonomi akan menunjukkan konsekuensi positif yang terwujud dalam bentuk behavioral, kognitif dan afektif. 
Kedua, Schunk, dan Zimmerman (Cubukcu, 2009) menyatakan bahwa keyakinan personal tentang kemampuan seseorang dan penguasan keterampilan dibutuhkan dalam belajar berdasar regulasi diri. Ketika seseorang melakukan penilaian diri pada fase rekfleksi diri belajar berdasar regulasi diri, keyakinan bahwa mereka telah mengalami peningkatan dalam belajar, akan meningkatkan efikasi dirinya (Zimmerman, 2000; \& Pintrich, 2004). Dalam teori determinasi diri, keyakinan diri dapat diperoleh melalui kepuasan kebutuhan kompetensi, yaitu keyakinan bahwa mereka dapat melakukan tugas tertentu secara efektif dan efisien (Guay, dkk., 2008). Eksperimen yang dilakukan oleh Deci yang dikutip oleh Deci, dkk. (1996), ditemukan bahwa mahasiswa yang diberitahu bahwa mereka bagus dalam pemecahan masalah teka-teki menunjukkan bukti keterlibatan yang lebih tinggi dibanding dengan yang tidak mendapatkan umpan balik tersebut.

Selain pemenuhan kebutuhan kompetensi meningkatkan keyakinan diri, kebutuhan otonomi juga dapat meningkatkan keyakinan diri. Bukti penelitian yang menunjukkan hal tersebut menunjukkan bahwa kepuasan kebutuhan ootonomi menghasilkan peningkatan motivasi intrinsik, persepsi diri, dan penghargaan diri dari waktu ke waktu (Niemic \& Ryan, 2009), memprediksi efikasi diri matematika siswa (Collins \& Usher, 2013), peningkatan keyakinan pada kompetensi dalam belajar, menunjukkan penyesuaian psikologis seperti kecemasan yang rendah dan penghargaan diri yang tinggi (William \& Deci, 1998), memprediksi peningkatan otonomi belajar berdasar regulasi diri, perasaan mampu, berminat, dan penurunan tingkat kecemasan selama semester (Black \& Deci, 2000)
Ketiga, mencari bantuan akademik yang termasuk dalam area regulasi konteks belajar berdasar regulasi diri menurut Pintrich (2004) sangatlah susah dibanding dengan area regulasi lainnya. Hal ini disebabkan karena tidak semua area regulasi berada dalam kontrol individu, tetapi juga ada pada lingkungan. Dengan demikian, untuk menfasilitasi mahasiswa dalam area regulasi ini, kepuasan kebutuhan keterkaitan perlu diakomodir. Mahasiswa perlu merasakan dukungan atau terkoneksi dengan lingkungan dalam hal ini dosen, teman (peer group), atau siapa saja yang terlibat dalam pembelajaran mereka. Payakachat, dkk. (2013) juga melaporkan bahwa perilaku mencari bantuan akademik secara positif berkorelasi dengan hubungan positif antara mahasiswa farmasi dengan staf fakultas. Staf pengajar yang dipersepsikan membantu, mudah didekati, dan bersahabat meningkatkan keterlibatan dalam perilaku mencari bantuan yang adaptif.

Jika orientasi tujuan mastery approach meningkatkan perilaku mencari bantuan adaptif karena pandangan bahwa mencari bantuan merupakan solusi untuk menyelesaikan masalah dan suatu cara untuk meningkatkan diri atau kesempatan untuk belajar (Newman \& Schwager, 1995), Kepuasan kebutuhan keterkaitan menghasilkan persepsi pada individu tentang adanya kesempatan untuk belajar yang diberikan oleh lingkungan sosial. Oleh karena itu, berdasarkan uraian ini, dapat disimpulkan bahwa kombinasi kedua prediktor ini merupakan refleksi dari esensi formulasi triadik Bandura (Zimmerman ,1989). Dengan demikian kata kunci belajar berdasar regulasi diri adalah saling ketergantungan lingkungan sosial dengan pengaruh diri (Zimmerman, 2000). 
Kecilnya kontribusi secara parsial yang disumbangkan oleh variabel independen dalam model regresi penelitian ini, tentu saja tidak seperti yang diharapkan karena secara teoritis dan adanya dukungan hasil empiris tentang keterkaitan komponen kepuasan kebutuhan dasar psikologis dengan komponen belajar berdasar regulasi diri seharusnya juga dapat memberikan kontribusi yang lebih besar. Nilai kontribusi yang kecil ini mungkin dapat dijelaskan oleh beberapa hal. Pertama, meskipun teori determinasi diri menjelaskan bahwa ketiga kebutuhan ini bersifat universal dan dibutuhkan oleh setiap individu tanpa mengenal budaya, usia maupun gender, namun terkait dengan otonomi (salah satu jenis kebutuhan dalam teori determinasi diri yang keuniversalannya menjadi perdebatan) menurut Deci dan Ryan (2000) mungkin terdapat perbedaan pada bagaimana otonomi diekspresikan dalam budaya individualis dan kolektivis. Dia mencontohkan bahwa pada budaya kolektivis, individu masih dapat termotivasi ketika dia melakukan sesuatu karena tuntutan kelompok. Dalam teori determinasi diri, hal ini menurut Deci dan Ryan (2000) disebabkan karena individu dapat menginternalisasi nilai tersebut atau menjadikannya bagian dari diri mereka. Jika hal tersebut terjadi, menurut Bao dan Lam (2008), individu ini akan tetap merasa seakan-akan mereka memiliki kebebasan memilih meskipun mereka bertindak atas dasar tuntutan kelompok. Sehingga ada kemungkinan subjek penelitian juga berpandangan demikian. Kedua, Bao dan Lam (2008) melaporkan bahwa dari tiga studi yang dilakukannya pada subjek dengan budaya kolektivis, mereka menemukan secara konsisten efek dari pilihan dimoderasi oleh keterkaitan sosioemosional individu dengan pembuat pilihan/keputusan. Ketika mereka memi- liki hubungan yang baik dengan orang yang membuat pilihan untuk mereka, motivasi mereka akan sama kuatnya dan mereka seakan telah membuat pilihan sendiri. Dalam keadan ini, berarti menurut Bao dan Lam (2008) efek pilihan personal tidak lagi menjadi sesuatu yang superior bagi individu.

Deci dan Ryan (2000) menjelaskan bahwa jika individu telah menginternalisasi pilihan yang dibuat oleh orang yang mereka percaya, mereka kemungkinan besar telah mengalami atau terpenuhi kebutuhan otonominya meskipun mereka tidak membuat pilihan. Makna otonomi dalam hal ini dapat berarti sejauh mana individu menerima secara penuh, mendukung, atau menerima aksi seseorang (Deci \& Ryan, 2000). Berdasarkan penjelasan kedua hal tersebut di atas, kecilnya kontribusi secara parsial mungkin dikarenakan konstruk otonomi dalam penelitian ini lebih bermakna otonomi dalam budaya individualistis dan tidak termasuk makna otonomi seperti yang dikemukakan oleh Deci dan Ryan (2000) yang mungkin dialami oleh individu dengan budaya kolektivis seperti subjek dalam penelitian ini.

\section{Kesimpulan}

Berdasarkan hasil analisis statistik dan pembahasan dapat disimpulkan bahwa kepuasan kebutuhan dasar psikologis dan orientasi tujuan mastery approach secara bersama-sama dapat secara signifikan memprediksi belajar berdasar regulasi diri. Dengan demikian peningkatan belajar berdasar regulasi diri mahasiswa dapat ditentukan oleh pemenuhan kepuasaan kebutuhan dasar psikologis, dan adopsi mahasiswa terhadap orientasi tujuan mastery approach.

Temuan hasil penelitian ini sangat penting dan berimplikasi pada pengembangan model pembelajaran di 
perguruan tinggi yang dapat meningkatkan kemandirian belajar mahasiswa dengan belajar berdasar regulasi diri.

\section{Saran}

Pembelajaran di perguruan tinggi sebaiknya menciptakan model pembelajaran yang menfasilitasi pemenuhan kepuasan kebutuhan dasar psikologis dan menstimulasi adopsi orientasi tujuan mastery approach untuk meningkatkan belajar berdasar regulasi diri mahasiswa. Adapun saran untuk penelitian selanjutnya adalah memasukkan variabel determinan lainnya yang dapat berkontribusi terhadap belajar berdasar regulasi diri mahasiswa, perlu mendefinisikan ulang konsep otonomi menyesuaikan konteks budaya subjek penelitian, mengembangkan skala belajar berdasar regulasi diri dengan mempertimbangkan kemungkinan adanya variasi pada setiap domain pengetahuan, dan memasukkan area regulasi motivasi/afeksi mahasiswa yang tidak dibahas dalam penelitian ini agar mendapatkan gambaran yang lengkap tentang regulasi diri mahasiswa dalam semua aspek regulasi pada pembelajaran di perguruan tinggi.

\section{Kepustakaan}

Ames, C., \& Archer, J. (1988). Achievement goals in the classroom: Students' learning strategies and motivation processes. Journal of Educational Psychology, 80(3), 260-267.

Ames, C. (1992). Classrooms: Goals, structures, and student motivation. Joumal of Educational Psychology, 84(3), 261-271.

Arabzadeh, M., Kadivar, P., \& Dlavar, A. (2012). The effects of teaching selfregulated learning strategy on students' academic delay of gratification. Interdisiplinary Journal of Contemporary Research Business, 4(2). doi: 10.1111/j.1365-2729.2007.00258.x

Artino, A. R. (2005). A review of the motivated strategies for learning questionnaire. ERIC.Ed.Gov. Institute of Education Sciences. ED499083.

Ashar, K. (2012). Tahun 2012 jumlah mahasiswa S1 FEB UB yang drop out sebanyak 70 orang. Diunduh dari: http://feb.ub.ac.id/tahun-2012-jumlahmahasiswa-s1-feb-ub-yang-di-dropsebanyak-70- orang. html\#. VBY pi6M ZhOw tanggal 12 September 2014.

Bandura, A. (1986). Social foundations of thought and action: A social cognitive theory. New Jersey: Prentice Hall, Inc. Englewood Cliffs.

Bao, Xue-hua \& Lam, Shui-fong. (2008) Who Makes the Choice? Rethinking the Role of Autonomy and Relatedness in Chinese Children's Motivation. Child Development, 79(2), 269 - 283.

Baumeister, R. F., \& Leary, M. R. (1995). The need to belong: Desire for interpersonal attachment as a fundamental human motivation. Psychological Bulletin, 117(3),497-529.

Bayrami, M., Yari, M., Khani, M., \& Mohammadi, N. (2014). Prediction of test anxiety on mathematics achievement goal orientation and self concept. Indian Journal of Fundamental and Applied Life Sciences, 4(3) 24-29.

Bembenutty, H, McKeachie, W. J., Karabenick, S. A., \& Lin, Y. (1998). The relationship between test anxiety and selfregulation on students' motivation and learning. A paper presented at the Annual Meeting of the American Psychological Society. Washington, DC.

Betoret, F. D., \& Artiga, A. G. (2011). The relationship among student psycho- 
logical need satisfaction, approaches to learning, reporting of avoidance strategies and achievement. Electronic Journal of Research in Educational Psychology, 9(2).

Biro Akademik UIN Makassar. (2014). Surat keputusan rektor UIN Alauddin Makassar. Nomor: 342 Tahun 2014 tentang pemberhentian (drop out) sebagai mahasiswa UIN Alauddin Makassar Tahun Akademik 2013/2014.

Black, A. E., \& Deci, E. L. (2000). The effects of instructors' autonomy support and students' autonomous motivation on learning organic chemistry: $A$ selfdetermination theory perspective. John Wiley and Sons, Inc.

Boekaerts, M., Pintrich, P. R., \& Zeidner, M. (2000). Handbook of self-regulation. Sandiego: Academic Press.

Boekaerts, M., \& Cascallar, E. (2006). How far have we moved toward the integration of theory and practice in self-regulation? Educational Psychology Review, 18, 199-210.

Broeck, A. V., Vansteenkiste, M., Witte, H.D., Soenens, B., \&, Lens, W. (2010). Capturing autonomy, competence, and relatedness at work: Construction and initial validation of the Workrelated Basic Need Satisfaction Scale. Journal of Occupational and Organizational Psychology, 83, 981-1002. doi:10.1348/096317909X481382.

Butler, R. (2007). Teachers' achievement goal orientations and associations with teachers' help seeking: Examination of a novel approach to teacher motivation. Journal of Educational Psychology, 99(2), 241-252.

Collins, J. S., \& Usher, E.L. (2013). Students' perceived autonomy support as a possible source of mathematics self-efficacy. University of Kentucky.
Cubukcu, F. (2009). Learner autonomy, self regulation and metacognition. International Electronic Journal of Elementary Education, 2(1), 54-64.

Darwati, Y. (2003). Kecenderungan mencari bantuan dalam belajar matematika ditinjau dari orientasi tujuan. (Tesis, tidak dipublikasikan). Universitas Gadjah Mada.

Deci, E. L., \& Ryan, R. M. (2000). The "what" and "why" of goal pursuits: Human needs and the self-determination of behavior. Psychological Inquiry, 11(4), 227-268. doi:10.1006/ ceps.1999.1020.

Deci, E. L., \& Ryan, R. M. (2008). Selfdetermination theory: A macrotheory of human motivation, development, and health. Canadian Psychology, 49(3), 182-185. doi: 10.1037/a0012801.

Deci, E. L., Vallerand, R. J. Pelletier, L. G., \& Ryan, R. M. (1991). Motivation and education: The self-determination perspective. Educational Psychologist, 26(3-4), 325-346.

Deci, E. L., Ryan, R. M., \& William, G. C. (1996). Need satisfaction and the selfregulated learning. Learning and Individual Differences, 8(3), 165-183.

Dupeyrat, C,. \& Mariné, C. (2005). Implicit theories of intelligence, goal orientation, cognitive engagement, and achievement: A test of Dweck's model with returning to school adults. Contemporary Educational Psychology, 30, 43-59. doi:10.1016/j.cedpsych. 2004.01.007.

Dweck, C., \& Legget, E. (1988). A socialcognitive approach to motivation and personality. Psychological Review, 95, 2, 256-273.

Dweck, C. S. (1986). Motivational processes affecting learning. American Psychologist, 41(10), 1040-1048. 
Elliot, A.J. (2005) A conceptual history of the achievement goal construct. Dalam Andrew. J. Elliot, Carol .S. Dweck. Handbook of competence and motivation. New York: The Guilford Press.

Elliot, E. S., \& McGregor, H. A. (2001). A $2 \times 2$ achievement goal framework. Journal of Personality and Social Psychology, 80(3), 501-5119.

Elliott, E. S., \& Dweck, C. S. (1988). Goals: An approach to motivation and achievement. Journal of Personality and Social Psychology, 54, 5-12.

Elliott, E. S., McGregor, H. A., \& Gabel, S. (1999). Achievement goals, study strategies, and exam performance: A mediational anaylisis. Journal of Educational Psychology, 91(3), 549-563.

Field, A. (2009). Discovering statitistik using SPSS (Third edition). Los Angeles: SAGE.

Filak, V. F., \& Sheldon, K. M. (2003). Student psychological need satisfaction and college teacher-course evaluations. Educational Psychology, 23(3). doi: 10.1080/ 01443410320000 60084.

Furrer, C \& Skinner, E. (2003). Sense of relatedness as a factor in children's academic engagement and performance. Journal of Educational Psychology, 95(1), 148-162. doi: 10.1037/00220663.95.1.148

Guay, F., Ratelle, C. F., \& Chanal, J. (2008). Optimal learning in optimal contexts: The role of self-determination in education. Canadian Psychology, 49(3), 233-240. doi: 10.1037/a0012758

Greene, B., \& Miller, R. B. (1996). Influences on achievement goals, perceived ability and cognitive engagement. Contemporary Educational Psychology, 21(2), 181-192. doi: 10. 1006/ceps.1996.0015
Gurcay, D., \& Balta, E. (2013). The effect of Turkish students' motivational beliefs on their metacognitive self-regulation in Physics. Asia-Pacific Forum on Science Learning and Teaching, 14(2).

Huijun, L., Dejun, G., Hongli, L., \& Peixia, G. (2006). Relationship among achievement goal orientation, test anxiety and working memory. Acta Psychological Sinica, 38, 254-261.

Ifenthaler, D. (2012). Determining the effectiveness of prompts for selfregulated learning in problem-solving scenarios. Educational Technology $\mathcal{E}$ Society, 15(1), 38-52.

Ilardi, B. C., Leone, D., Kasser, R., \& Ryan, R. M. (1993). Employee and supervisor ratings of motivation: Main effects and discrepancies associated with job satisfaction and adjustment in a factory setting. Journal of Applied Social Psychology, 23, 1789-1805. doi: 10.1111/j.1559-1816.1993.tb01066.x.

Jang, H., Reeve, J., Ryan, R. M., \& Kim, A. (2009). Can self-determination theory explain what underlies the productive, satisfying learning experiences of collectivistically oriented Korean students?. Journal of Educational Psychology, 101(3), 644-661. doi: 10.1037/a0014241

Kahraman, N. (2011). Antecedents and consequences of achievement goal. A thesis. The Graduate School of Social Sciences of Middle eat Technical University.

Keblawi, F. (2006). A review of language learning motivation theories. Jameea, 12, 23-57.

Lim, B. S. S., \& Wang, C. K. J. (2009). Perceived autonomy support, behavioural regulations in physical education and physical activity intention. Psychology of Sport and 
Exercise, 10, 52-60. doi: 10.1016/ j.psychsport.2008.06.003.

Livengood, J. M. (1992). Students motivational goals and belief about effort an ability as they relate to college academic success. Research in Higher Education, 33(2).

Marcou, A., \& Philippou, G. (2005). Motivational beliefs, self-regulated learning and mathematical problem solving. Dalam Chick, H. L. \& Vincent, J. L. (Eds.). Proceedings of the 29th Conference of the International Group for the Psychology of Mathematics Education, 3, 297-304.

Mattern, R. A. (2005). College students' goal orientations and achievement. International Journal of Teaching and Learning in Higher Education, 17(1), 2732.

Meece, J. L., Blumenfeld, P. C., \& Hoyle, R. H. (1988). Students' goal orientations and cognitive engagement in classroom activities. Journal of Educational Psychology, 80(4), 514-523.

Midgley, C., Kaplan, A., Middleton, M., Maehr, M. L., Urdan, T., \& Anderman, L. H. (1998). The development and validation of scales assessing students' achievement goal orientations. Contemporary Educational Psychology, 23, 113-131.

Miltiadou, M., \& Savenye, W.C. (2003). Applying social cognitive constructs of motivation to enhance student success in online distance education. AACE Journal, 11(1), 78-95.

Moller, A. C., \& Elliot, A. J. (2006). The 2x2 achievement goal framework: An overview of empirical research. Focus on Educational Psychology, pp 307-326.

Neuville, S., Frenay, M., \& Bourgeis, E. (2007). Task value, self-efficacy and goal orientation: Impact on self- regulated learning, choice, and performance among university students. Psychologica Belgica, 47(1/2), 95-117. doi: 10.5334/ pb-47-1-95.

Newman, R. S.(2002). How self-regulated learners cope with academic difficulty: The role of adaptive help seeking. Theory Into Practice, 41(2), 132-138.

Newman, R. S., \& Schwager, M. T. (1995). Students' help seeking during problem solving: Effects of grade, goal, and prior achievement. American Educational Research Journal, 32(2), 352-376.

Niemiec, C. P., \& Ryan, R. M. (2009). Autonomy, competence, and relatedness in the classroom. Theory and Research in Education, 7(2) 133-144. doi: 10.1177/1477878509104318.

Nolen, S. B. (1988). Reasons for Studying: Motivational orientations and study strategies. Cognition and Instruction, 5(4), 269-287.

Osterman, K. F. (2000). Students' need for belonging in the school community. Review of Educational Research, 70(3), 323-367. doi: 10.3102/0034654 307000 3323.

Paris, S. G., \& Paris, A. H. (2001) Classroom applications of research on self-regulated learning. Educational Psychologist, 36(2), 89-101.

Payakachat, N., Gubbins, P. O., Ragland, D., Norman, S. E., Flowers, S. K., Stowe, C. D., ... Hastings, J. K.. (2013). Academic help-seeking behavior Among student pharmacists. American Journal of Pharmaceutical Education, 77(1) Article 7.

Peverly, S. T., Brobst, K. E., Graham, M., \& Shaw, R. (2003) College adults are not good at self-regulation: A study on the relationship of self-regulation, note taking, and test taking. Journal of Educational Psychology, 95(2), 335-346. 
doi: 10.1037/0022-0663.95.2.335.

Pintrich, P. R. (1999). The role of motivation in promoting and sustaining self-regulated learning. International Journal of Educational Research, 31, 459470.

Pintrich, P. R. (2000). The role of goal orientation in self-regulated learning. Dalam M. Boekaerts, P. R. Pintrich, \& M. Zeidner (Eds.), Handbook of selfregulation (pp. 451-502). San Diego, CA: Academic.

Pintrich, P. R. (2004). A Conceptual framework for assessing motivation and self-regulated learning in college students. Educational Psychology Review, 16(4), 385-407.

Pintrich, P. R., \& De Groot, E. V. (1990). Motivational and self-regulated learning components of classroom academic performance. Journal of Educational Psychology, 82(1), 33-40.

Pintrich, P. R., \& Schunk, D. H. (1996). Motivation in education: Theory, Research, And Aplication. New Jersey: Englewood Cliffs.

Pintrich, P. R., Smith, D. A. F., Garcia, T., \& McKeachie, W. J. (1991). A manual for the use of the motivated strategies for learning questionnaire (MSLQ). Ann Arbor: University of Michigan, National Center for Research to Improve Postsecondary Teaching and Learning.

Pusat Penelitian UPI. (2010). Efektivitas model pembelajaran non direktif berbasis masalah untuk meningkatkan kemandirian belajar siswa. Lembaga Penelitian dan Pengabdian Masyarakat Universitas Indonesia.

Reeve, J., \& Halusic, M. (2009) How K-12 teachers can put self-determination theory principles into practice. Theory and Research in Education. Vol 7(2) 145-

\section{DOI: $10.1177 / 1477878509104319$}

Reeve, J. (2012). A self-determination theory perspective on student engagement. In S.L. Christenso, A. L. Reschly, \& C. Wylie (eds.), Handbook of research on student engagement. New York: Springer Science and Business Media, LLC.

Reeve, J., \& Sickenius, B. (1994). Development and validation of a brief measure of the three psychological need underlying intrinsic motivation: The AFS scales. Educational and Psychological Measurement, 54(2), 506515.

Ryan, A. M., Pintrich, P. R., \& Midgley, C. (2001). Avoiding seeking help in the classroom: who and why?. Educational Psychology Review, 13, 93 -114.

Ryan, R. M., \& Deci, E.L. (2006) Selfregulation and the problem of human autonomy: does psychology need choice, self-determination, and will?. Journal of Personality, 74(6), 1557-1585. doi: 10.1111/j.1467-6494.2006.00420.x.

Ryan, R. M. \& Deci, E. L. (2008). From ego depletion to vitality: Theory and findings concerning the facilitation of energy available to the self. Social and Personality Psychology Compass, 2(2), 702-717. doi: 10.1111/j.1751-9004.2008. 00098.x.

Ryan, R. M., Stiller, J. D., \& Lynch, J. H. (1994). Representation of relationship to teachers, parents, and friends as predictor of academic motivation and self-esteem. Journal of Early Adolescence, 14(2), 226-249.

Sadeghy, A. R., \& Mansouri, A. (2014). The relationship between learners' goal oriented and self-regulated learning and their endorsement of L2 learning strategies. International Journal of Language Learning and Applied 
Linguistics World, 5(2).

Sierens, E., Vansteenkiste, M., Goossens, L., Soenens, B., \& Dochy, P. (2009). The synergistic relationship of perceived autonomy support and structure in the prediction of self-regulated learning. British Journal of Educational Psychology, 79, 57-68. doi: 10.1348/000709908X304 398.

Somuncuoglu, Y., \& Yildirim, A. (1999). Relationship between achievement goal orientations and use of learning strategies. The Journal of Educational Research, 92(5), 267-277.

Sungur, S., \& Gungoren, S. (2009) The role of classroom environment perceptions in self-regulated learning and science achievement. Elementary Education Online, 8(3), 883-900.

Susetyo, Y. F., \& Kumara, A. (2012) Orientasi Tujuan, Atribusi Penyebab, dan Belajar Berdasar Regulasi Diri. Jurnal Psikologi, 39(1), 95 - 111.

Tapola, A., \& Niemivirta, M. (2008). The role of achievement goal orientations in students' perceptions of and preferences for classroom environment. British Journal of Educational Psychology , 78, 291-312. doi: 10.1348/000709907X205272.

Valle, A., Núñez, J. C., Cabanach, R. G., González-Pienda, J. A., Rodríguez, S., Rosário P., ... Muñoz-Cadavid, M. A. (2008). Self-regulated profiles and academic achievement. Psicothema, 20(4), 724-731.

Villach, M. J., \& Lianos, M. N. (2007). Fostering self-regulated learning in an assessment situation. Electronic Journal of Research in Educational Psychology,
5(3), 805-824.

Williams, G. C., \& Deci, E. L. (1998). The importance of supporting autonomy in medical education. Annals of Internal Medicine, 129, 303-308.

Winne, P. H. (2005). A perspective on state-of-the-art research on selfregulated learning. Instructional Science, 33, 559-565. doi: 10.1007/s11251-005-1280-9.

Zimmerman, B. J. (1989). A social cognitive view of self-regulated academic learning. Journal of Educational Psychology, 81(3).

Zimmerman, B. J. (2000). Attaining selfregulated :A social cognitive perspective. Dalam M. Boekaerts, P. R. Pintrich, dan M Zeidner. Handbook of Self-Regulation. Sandiego: Academic Press. pp. 13-39.

Zimmerman, B. J. (2002). Becoming a selfregulated learner: An overview. Theory Into Practicve, 41(2), 64-70.

Zimmerman, B. J. (2008). Investigating self-regulation and motivation: Historical background, methodological developments, and future prospects. American Educational Research Journal, 45(1), 166 -183. doi: 10.3102/0002831207312909.

Zimmerman, B. J., \& Kitsantas, A. (2005). The hidden dimension of personal competence: Self-regulated learning and practice. Dalam Andrew J. Elliot \& Carol Dweck. Handbook of competence and motivation. New York: The Guilford Press (pp. 509-526). 